Issue $3 / 2017$

\title{
CONNECTION BETWEEN ECONOMICS, CULTURE AND CULTURAL DIPLOMACY
}

\author{
Agil VALIYEV ${ }^{1}$ \\ ${ }^{1}$ Ph.D. on International Relations at ANAS, Lecturer at Azerbaijan \\ Tourism and Management University, Baku, Azerbaijan, Tel.: +994503616211, \\ Email: agil.oyu@gmail.com, ir.minedu@gmail.com
}

\begin{abstract}
Today, culture is one of the main feeble factors of economic development. The leading role of culture in economic development should be argued as multiple: so, firstly, as domestic value, secondly, as a main factor of regional economic development advanced to raised gravity of different regions for residents, tourists and investors, thirdly, as major parameter of social development based on tolerance, creativity and knowledge. To the different international experiences, culture is the main part of economic development in our life. Cultural diversities are combined into a main reasonable economic development model. The article consist of explanations about the understanding of culture, cultural diplomacy and economics, approach on the conflicts between culture and economics, to find how is culture affecting the economic development, and the role of culture in economic development of Azerbaijan. The article can be considered as a useful resource for experts and researchers conducting research in this field.
\end{abstract}

Keywords: culture; economics; cultural diplomacy; intercultural dialogue; foreign policy; growth; development.

JEL Classification: $\mathrm{M}_{14}$

\section{Understanding Economics and Culture}

Today's world culture unorganizes our reasonableness and availability in a shape that may be called creative, and also covers the access for hopeless requirements for new services and products that fill up the open fractions. A specific and combined new shape of cosmopolitanism, adjusting market rules, personal consumerism, technology and science and, previous but not least, connections and cultural industries, has stuck out. 


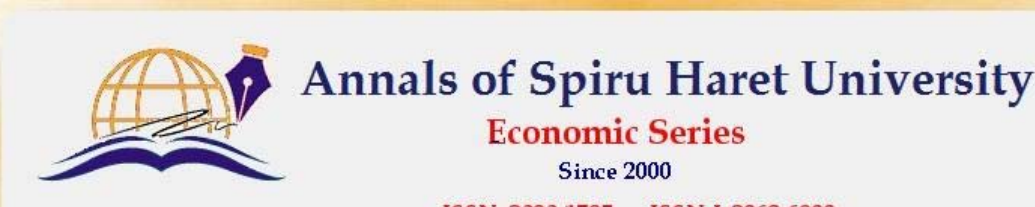

ISSN: 2393-1795 ISSN-L:2068-6900

Issue 3/2017

Moreover, culture can participate as a part of foreign policy of a country: the organization and designation of cultural policy is an assignment which is given to the foreign policy winding up [1, p. 215; 2, p. 409], also, is understood as the cultural diplomacy between different nations [3, ch. 1].

Culture is mainly an important factor of international relations because of the globalization and progress in IT technologies that repair the strength dynamics between various social participants.

The cultural measurement has been progressively combined in the economic, political, and social programs of governments. This has concluded in policy views and institutional delivering a various investment of national interests in national, local and international circumstances. 'Culture' is now broadly received as a resource, capital $[4$, p. 3], and power [5, p. 7]. Thus, we can say that "depend the economy and the power to be internationalized to the stretch that they are culturalized" [6, p. 12].

Culture is a connected reflection of economics and politics in any community. Forever, culture can also be comprehended as a type of efficient force. So, culture is explained as the collective, intellectual programming which differentiates one small group or some category of people from another. This agenda impact the examples of thinking, which are expressed in the significance people give to the various features of their lives, and consequently help form the institutions of a community.

Culture which initiates one of the basic components of readiness to life in community plays a special role in the progress of social capital. Hereby, culture linked commitments ensure, to a certain extension, the intellectual possibility of regions and the building of a judicious, open and broad-minded citizen community. It should be stressed that culture is a source for commencing cooperation and human relations, implementing numerous education activities and thus activating different layers of community. [13]

Today, cultural industries are described by a top level of creativity and innovation in the market, where most services and goods cannot be necessarily replaced. Beside it, cultural industries establish jobs outside the state sector. Different cultural industry branches in which small and middle-sized enterprises command have big employment opportunity and are heavily hardened in local societies and regional connections. It should be noted that, cultural industries are the branch of the economy with the biggest employment parameter. They make a big number of works, in an age of damp or even standstill of the world economy. The branch of culture industries is today, after endure varieties aroused by overinvestment in computer-network branch - the most actively growing branch of the 68 


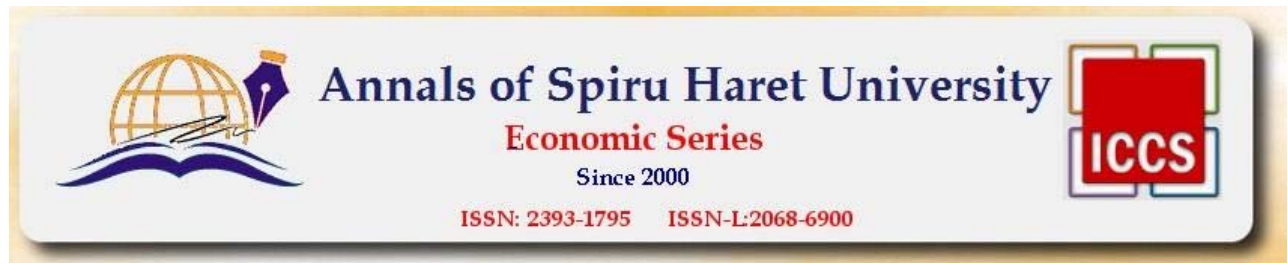

Issue $3 / 2017$

world economy. It makes economic factors stable due to the top level of last product transformation process.

But, cultural diplomacy is best explained as "the exchange of art, information, ideas and other features of culture among different nations and their peoples to tremble mutual understanding”. [7, p. 1]

A common point of view is that, however cultural diplomacy can help set up and assist working contacts between countries, it is seriously dependent on the difficult items of laws and bilateral negotiations, agreements, military capability and multilateral structures.

\section{Conflicts between Culture and Economy}

Not always this familiar relationship between economy and culture is positive. So, there are remembrances of the modern culture as a key adherent of "alienation", "mass hedonism", a consumeristic "logic of surplus", fuelled by "promotion overdoses", establishing a set of "overmuch" and unreasonable choices, among other obstinacies. Culture, in this more worldly and prosy version, has become so involved in the economy where it has make the advantages - and be subjected to the imprecation - of invisibility. [8, p. 4]

The conflicts between the reigns of economy and culture are very visible. However, one must finally recognize that there are seven difficult problems to this connection:

1. The embarrassment of value - the economy and economics seem to be concentrated on the value of interchange, where culture deals with non-material, hard to measure values.

2. The obstacle of exchange - whereas the economy prospers in estimation, confrontation and exchange, these opinions are much combined when addressed to culture.

3. The embarrassment of time - most appreciations altered in markets seem to deal with current delight and contentment, while many of the consequences of culture and art are to get pleasure by still expected, our future generations.

4. The embarrassment of joint nature - whereas cultural artefacts and goods are to be estimated jointly and cannot be fully suitable, most products closed in daily shopping centres and markets are separately prospered.

5. The embarrassment of the non-material - services and goods interchanged in the economy cherish to have a material, physical availability, whereas many cultural goods do not.

6. The embarrassment of "the other" - is always individual, but, whereas weighing the advantages of various individuals is excepted in economics, and it is at the pith of authenticity, creativity, even genius. 

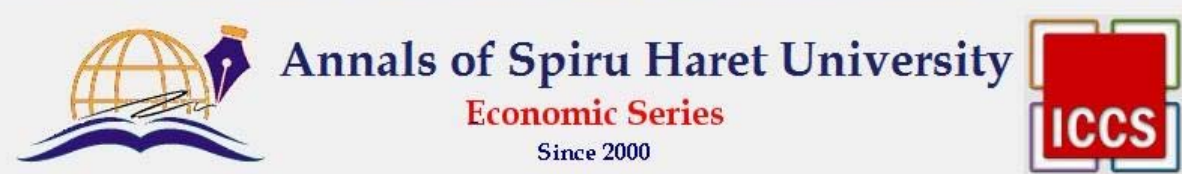

Issue $3 / 2017$

7. The obstacle of balance - whereas economics takes benefits from the concept of balance, culture and art often tread in collapsing and dramatic newness.

\section{How Does Culture Affect Economic Development?}

Until recent days, economists have been unwilling to trust culture as a possible definition of the economic fact. In respect of today's canon, unless a community has policies and institutions that ensure for secure specific possessions, freedom on agreement, limited range of adjustment, monetary self-control, financial liability and open commerce, the community will not experiment longterm economic development and growth. The customary theory colludes that any preferences a culture may have, they will not be implemented under bad organizations. Moreover, any disadvantages a culture may have, they will quietly erode, and the culture will increase, when all people get to live under economic and political freedom. So, culture can act as a sadness, but it is also a pliable constraint. [14]

In the last ten years, Guiso, Sapienza, and Zingales, as well-known economists, have investigated the connection between values, culture, personal advantages and the economy, concentrating on the unidirectional effects of culture on the economy. So, they have displayed practically, for example, that the standard of confidence that all persons have in their country's organizations and all citizens affect many viewpoints of economic action. When a state opens its doors to global business, goods planned for a "international consumer" reach on its market, thus increasing the lifestyle of people who are sensitive to this type of goods. [15]

In order to identify the link from culture to economic consequences, we determine culture as those common values and beliefs that religious, ethnic and social minorities hand over almost unaltered from generation to generation. So, this kind of determination includes two main key points:

- Firstly, the top definition of culture confines the possibility channels of impact to two standard ones; values like advantages and beliefs like priors. In this regard, we find an explanation for a substantial problem: in all issues on economics and culture, causation is likely to go both directions, from economics to culture and from culture to economics. [9, p. 3] As a result, while not satisfactory, this view focuses on those patterns of culture that can influence economic results and permit us to define a major effect from culture to economic inferences.

- Secondly, it delivers that culture is outside the personality, it is not located in the memories and motions of each individual person, and rather, it turns to the press to which persons are emptied by miracle of living in proper social systems. 


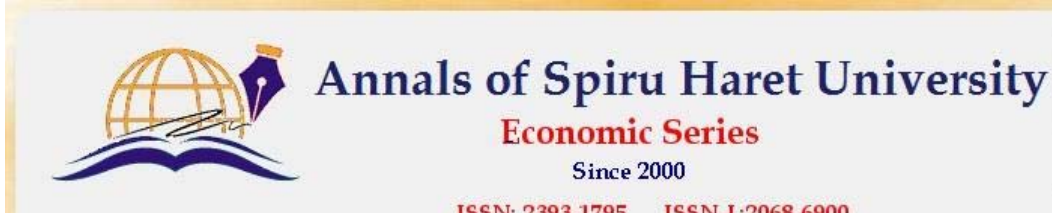

ISSN: 2393-1795 ISSN-I-2068-6900

Issue $3 / 2017$

Thereby, in this approach, culture is seen as an "heritable ethical custom", as well as "what is passed from one generation to other, via teaching and mimicking of values, knowledge, and other factors which affect behaviour" [12].

Culture influences economic action through the options that all people prepare about how to determine limited resources. In other conditions, while culture may be an essential definition of economic action, it acts within proximate aspects like the assembling of capital, the acceptance of technology, or labour market complicity judgements. [16]

The European Commission acknowledges a variation in its view to culture policy. Hereby, the focus is now further side of traditional classifications of cultural expenses, in direct of a more proven structure for progressing the creative and cultural industries. The major process is to assume a review of the creative and cultural benefits of the various regions and recruit them for the three various growth perspective directions of Europe 2020. This impresses a move in direction of a wider involvement of culture as an instrument for social and economic development, acknowledging culture as a provider of significant spill over impacts into other economic branches.

We operate such kind of examples of particular cultural policies followed in Europe and North America, and systematize how each indemnifies to economic development, however a specific set of material and non-material results. We discover that Portugal gets on poorly in terms of the significance of the cultural branch, in its various guises. Thus, in the cross-sector of European countries, we discover that cultural attendance and the measure of the cultural branch are closely connected to sizes of inclusiveness and innovation at the local level. In addition, indexes of involvement and innovativeness are lower in Portugal than what would be forecasted given its powerless cultural section.

\section{The Role of Culture in Azerbaijan's Economic Development}

After gaining independence from Soviet Union, Azerbaijan has taken significant measures, in particular, in order to preserve the national cultural values, to extend the cultural life, and has started to collaborate with different international organizations in this field. A number of necessary legislations have been adopted by the Azerbaijani Parliament in the cultural spheres. [17]

In Azerbaijan, the practical experiences and the conception of culture in foreign relations pursue customary cultural diplomacy views based on different models of nation branding. Since the country is in a stage of nation building, Azerbaijan's cultural branding is a stretching task for some causes. Hereby, one of 


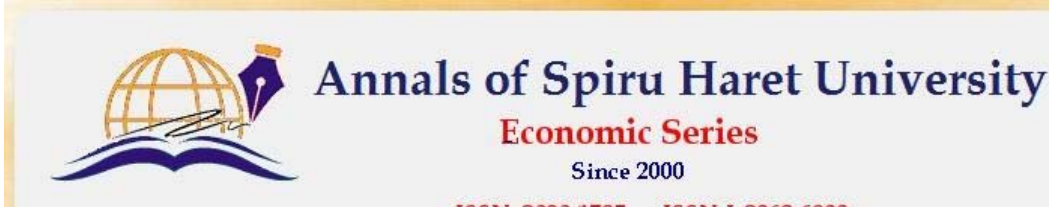

ISSN: 2393-1795 ISSN-L:2068-6900

Issue $3 / 2017$

them, the area of Azerbaijan is still broke up: the country is not only separated between the mainland and the autonomy region of Nakhchivan, but is also cut down from Nagorno Karabakh. So, Azerbaijan and Armenia still have to settle down the Nagorno Karabakh conflict. In this regards, their particular Diasporas are involved in the solving of the process. On second hand, as nation, the Azerbaijani people meet another issue - the country mainly consist of Azeri Turks, a big number of people who mostly live in modern Iran. [18]

Various strategies on culture in foreign affairs are primarily conveyed in the conditions of the country's cultural diplomacy, the 'advertisement of Azerbaijan', intercultural dialogue, as well as, recently, cultural tourism. [10, p. 14, p. 28]

The aspect of culture imagined in the country's foreign affairs is obviously linked to the conception of cultural diplomacy: state principle and running mostly along external policy aims. Thereby, intercultural dialogue is a cultural policy territory which is invested by the government, and utilizes the preferences of Azerbaijan as a cultural and geographical hub. Cultural tourism is a new perspective section and is presented as an important vector of reciprocal understanding, as well as a mechanism for development. [11]

Beside it, Azerbaijan has been able to build an affirmative identity, which needs too much attention and appreciation, that's why we can find a lot of identities in our world which are constructed on negativities. So, Azerbaijan's external policy strategy and geo-political identity give an opportunity to make neutral foreign threats and to answer flexibly to the international changes. [19]

According to local marketing, the government follows different long term plans for the modernization of cultural policy, with the construction and rebuilding of large-measured cultural constructions (example: new Heydar Aliyev Cultural Centre, the Carpet Museum, and the International Mugham Centre). Government representatives have invested to digitalize cultural diplomacy throughout the establishment of web-based show window platforms and websites. This kind of issue is becoming a must for the abundance of cultural organizations in Azerbaijan.

Today, Baku organizes the main important international summits, events and conferences to discuss important tasks of the modern period and cooperation. Some of them are the Global Open Society Forum, the Davos Economic Forum, Baku Humanitarian Forum, Intercultural Dialogue Forum, the World Summit of Religious Leaders, Eurovision song contest, the World Youth Forum, the 3rd Forum on Intercultural Dialogue, Baku 2015 European Games, the 7th Global Forum of the United Nations Alliance of Civilizations, and other international important events. So, the European Games were not only a sport competition in life of any country. 


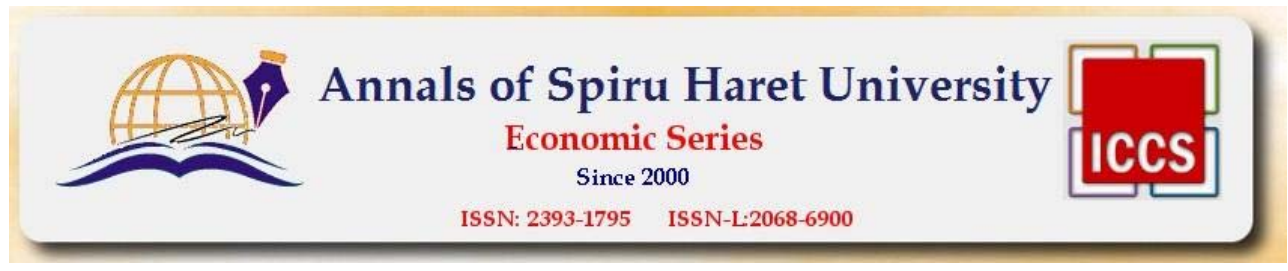

Issue $3 / 2017$

This sport competition plays a main role in furnishing peace, mutual understanding and security in the modern world. Today, the geopolitical affinities in different circles are so strong that even sports are impotent here. Hereby, these kind of big cultural events help to develop the economy of Azerbaijan under its cultural diplomacy.

\section{Conclusion}

In answering the question of what makes economic increase happen, most economists go into detailing these inequalities by appealing to the list of terms that must be met for an economy to develop. Good governance is seen as an introduction of development: the political system should be durable; rights must be openly promulgated and materialized so that contractual agreements will be respected; government officials should not be corrupt or unproductive. In addition, land should be available at a fair rate for business possibilities; foreign investment should be stimulated; the official methods for obtaining a business permit should not be too painful. Moreover, each economy experiments significant flow abilities in growth rates year after year as an outcome of parameters such as technological shocks or unforeseen circumstances that affect the result.

Research found that explanation of culture, economics and cultural diplomacy explained the connection among them, to find the affecting of culture to economic development and the role of culture in economic development of Azerbaijan.

\section{References}

1. Akira Jriye, "Culture and International History", in Michael J. Hogan and Thomas G. Paterson (eds.), Explaining the History of American Foreign Relations (New York, 1991), p. 215.

2. Peter Duignan \& Lewis H. Gann, The Rebirth of the West. The Americanization of the Democratic World. 1945-1958 (Cambridge, Mass., 1992), p. 409.

3. Frode Liland, De som elsket Amerika. Kollektive forestillinger om Amerika i Norge 1945-1949 [Those Who Loved America. Collective Images of America in Norway 1945-1949J (MA thesis in history, University of Oslo. Fall 1992), ch. 1.

4. Nye, J., "Soft Power: The Means to Success in World Politics", Public Affairs, 2004, p. 7.

5. Cummings, Milton C., Cultural Diplomacy and the United States Government: A Survey (Centre for Arts and Culture, 2003), p. 1.

6. Gabinete de Análise Económica - GANEC, Culture and Economic Development: A Guide for Policy-Makers, 2014, p. 4.

7. Guiso, L., Sapienza, P. \& Zingales, L., Does Culture Affect Economic Outcomes? (National Bureau of Economic Research, 2006), p. 3. 


\section{Annals of Spiru Haret University Economic Series Since 2000 \\ ISSN: 2393-1795 ISSN-L:2068-6900}

Issue $3 / 2017$

8. Council of Europe, 'Azerbaijan', Compendium, op. cit., p. 5, quotes the Law on culture. Terry Sandell (et al.), "Analytical Base-line report on the culture sector and cultural policy of the Republic of Azerbaijan”, EuroEast culture, January 2013, p. 14, p. 28.

9. Speech of Minister of Culture of Azerbaijan Republic at the Tbilisi Ministerial Conference on culture of the Eastern Partnership, 27-28 June 2013.

10. Shixue, J., Cultural Factors and Economic Performance in East Asia and Latin America, 2003. Retrieved from Chinese Academy of Social Sciences website in October 2014, available at: http://bic.cass.cn/english/infoShow/Arcitle_Show_Forum2_Show.asp ?ID=318\&Title=The+Humanities+Study\&strNavigation=Home-\%3EForum\&Big ClassID $=4 \&$ SmallClassID $=8$

11. http://poieinkaiprattein.org/europe/economy/culture-and-economy/culture-as-a-factorof-social-and-economic-development---the-polish-experience-by-karolina-tylus/

12. https://www.academia.edu/12973858/HOW_DOES_CULTURE_AFFECT_ECONOMI C_DEVELOPMENT

13. http://gnp.advancedmanagement.net/article/2015/05/culture-and-economy-understanding-dynamics-globalization

14. https://growthecon.wordpress.com/2014/06/18/does-culture-matter-for-economicgrowth/

15. "Social and cultural issues" - www.mfa.az

16. http://ec.europa.eu/assets/eac/culture/policy/international-cooperation/documents/ country-reports/azerbaijan_en.pdf

17. http://sam.az/uploads/PDF/Role\%20of\%20Azerbaijan\%20RGA.pdf 